CHAPTER 6

\title{
Lavoisier, Phosphorus, and the Role of Mitouard
}

THERE still remains an unexplained aspect of the early combustion experiments of Lavoisier. As we have seen, he had planned-as early as August 8, 1772-to investigate the calcination and reduction of metals in closed vessels using the burning glass and a modification of Hales's pedestal apparatus. Yet it is well known, and we have repeatedly emphasized, that the first experiments he actually performed were those on phosphorus and sulphur and that the famous reduction of minium was not carried out until late October. If possible, we should account for this delay and ask ourselves in what mannerafter having hit upon the idea that air might combine with metals-he was led to investigate the possible absorption of air by burning phosphorus.

\section{The Minium Experiment}

To understand the delay we must say a word or two more about Lavoisier's activities during the summer and early fall of $\mathbf{1 7 7 2}$. In the spring of that year-when with Macquer and Cadet he was experimenting on the dia- 


\section{PHOSPHORUS AND MITOUARD}

mond-it was several times remarked that the conflicting results obtained by different workers might be due to a failure to employ sufficiently high, and therefore, for all practical purposes, sufficiently comparable, furnace temperatures. It was proposed that the experiments be repeated by the spectacular method of the earlier Florentine experimenters, namely, by employing a powerful burning mirror or burning glass. This, it was pointed out, would ensure temperatures immeasurably higher than any that could be supplied by a furnace. After some preliminary tests Cadet and Brisson asked the Academy, in July, for permission to take from its cabinet of curiosities the great lens of Tschirnhausen which had been used earlier in the century by Homberg and Geoffroy for their experiments on various mineral substances and in the focus of which Homberg, for example, claimed he had calcined and vitrified gold. ${ }^{1}$

The Academy readily granted this request and at the same time extended an invitation to other members-in particular, Macquer and Lavoisier-to share in the pro-

${ }^{1}$ See Macquer's report on these experiments (Introduction aux observations, II, 612-616). A more detailed account of the preparations is given by Lavoisier in an unpublished manuscript; he attributes the initiative to Cadet, who believed the use of a burning glass would provide evidence for or against his decrepitation theory and who performed with Brisson some preliminary experiments with a small burning glass belonging to the latter. Finding this too small to be effective, he thought of asking the Academy for the use of the Tschirnhausen lens, the so-called "lentille du Palais Royal," and in July "MM. Cadet et Brisson demanderent a l'academie la permission de tirer de Son Cabinet et la lentille et Sa monture aussy que quelques autres instrumens qui paroissoient necessaires pour Cette Operation" (Lavoisier papers, archives of the Academy of Sciences, dossier 72 J, see Appendix II). 


\section{LAVOISIER-THE CRUCIAL YEAR}

posed experiments. The investigators needed a location in the open air, where they could erect a shed or conservatory (un hangard ou espèce de serre) to house and shelter the lens. The site hit upon was the so-called "Jardin de l'Infante," a terrace running southward from the old Louvre to the quai and adjacent to a ground-floor apartment of the palace, which could be at the disposal of the experimenters. By a further piece of good fortune a second Tschirnhausen lens, with the same diameter as the Academy's lens but with a shorter focal length, was lent by its owner, the Comte de la Tour d'Auvergne. The investigators were thus able to begin their experiments by the middle of August, 1772, with the two largest and strongest lenses yet made.

Lavoisier was actively engaged in this collaborative investigation from August 14, when the first experiment was carried out, until October 13. He had definite ideas as to how the equipment might profitably be used; indeed, as I have argued, the document he drew up on August 8, entitled "Réflexions sur les expériences qu'on peut tenter à l'aide du miroir ardent," was neither a memoir intended for publication, as some have claimed, nor yet a purely private memorandum, but a set of proposals intended to influence his coworkers. ${ }^{2}$ In this August memorandum Lavoisier suggested some experiments on minerals, stones, and refractory materials; but, as we have seen, he was particularly interested in work on the diamond and still more so in possible experiments on heating metals and metallic calxes in closed vessels.

The detailed record of these experiments makes it clear that Lavoisier's most striking proposals were for the most

2 See my "Lost Memoir of Lavoisier," loc. cit., p. 126. 
part ignored, and that it was the interests of the others which determined the choice of the experiments actually performed. These consisted almost exclusively in subjecting a wide variety of metals and mineral substances to the action of the burning glass in the open air. ${ }^{3}$ It is hardly surprising that Lavoisier was obliged thus to defer to his colleagues' wishes, and that his proposals were largely disregarded, for he was, after all, a junior of the group both in age and in academic rank.

It was not until the collaborative investigation was suspended in mid-October that Lavoisier was free to use the equipment for his own purposes. His historic experiments on minium were at last performed in the Jardin de l'Infante in the period between October 22 and November 1, using a simple adaptation of Hales's pedestal apparatus (Fig. 4). ${ }^{4}$ In the center of a basin of water

3 "Détails des expériences executées au moyen du grand verre ardent," Oeuvres de Lavoisier, III, 284-342. Lavoisier records: "MM. Cadet et Brisson Sentirent Combien il etoit importans de profitter de cette circonstance pour repeter tout ce qui avoit été fait par MM. homberg et Geoffroy avec le verre ardent et pour y ajouter de nouvelles experiences" (Lavoisier papers, dossier $72 \mathrm{~J}$, fol. 1 verso).

${ }^{4} \mathrm{~A}$ full description is given in Chapter $\mathrm{V}$ of the second part of the Opuscules where Lavoisier writes: "J’ai mis dans la capsule A [Fig. 4] 2 gros de minium, mêlés avec 12 grains de braise de boulanger, qui avait été préalablement réduite en poudre et calcinée à un grand feu pendant plusieurs heures dans un vaisseau fermé; jai marqué, avec une bande de papier collé, la hauteur $\mathrm{GH}$, jusqu'à laquelle j’avais élevé l'eau, et j’ai porté l'appareil, ainsi disposé, au foyer du grand verre ardent de Tschirnhausen, appartenant à $\mathrm{M}$. le comte de la Tour d'Auvergne; cette lentille était alors établie au Louvre, dans le jardin de l'Infante, pour d'autres expériences faites en société par MM. Macquer, Brisson, Cadet et par moi, et dont une partie est déjà connue de l'Académie des sciences" 
Lavoisier put a supporting column of crystal fixed in place by a bit of sealing wax; on top of it he placed a porcelain crucible. A crystal bell jar was inverted over the column with its crucible, and the basin was filled with water; when air was sucked out of the bell jar with a siphon, the water could be made to rise to any desired level, which Lavoisier then marked by a band of adhesive paper. A drop of oil was added on the surface of the water to prevent the discharged gas from dissolving. In the crucible he put his mixture of minium ${ }^{5}$ and special charcoal (braise de boulanger) and brought it into the focus of the burning glass. The lead oxide was rapidly reduced, and from the fall of the water level Lavoisier was able to estimate the quantity of elastic fluid that was given off.

(Oeuvres de Lavoisier, I, 599-600). The apparatus, his modification of Hales's pedestal apparatus, is described on the same page.

${ }^{5}$ In the sealed note of November 1 , where Lavoisier first refers to this experiment, he describes it as having been performed on "litharge"; here he refers to minium, which seems to be correct. Litharge, the reddish-yellow form of the monoxide $(\mathrm{PbO})$, produced by fusing lead in open vessels, is described by Macquer (Dictionnaire [1766], II, 266) as "une substance jaunâtre vitrifiée, mais qui reste en especes de petites écailles comme talqueuses." Minium or red lead $\left(\mathrm{Pb}_{3} \mathrm{O}_{4}\right)$, the scarlet crystalline powder resulting from further oxidation, was not readily produced in the laboratory in Lavoisier's time but was commercially available. Macquer says (ibid., p. 123) that all the commercial minium was produced "en grand" in Dutch factories; he is not sure just how. Lavoisier, in his registres of 1773 , is more careful about his terminology than he was in his sealed note; he cites numerous repetitions of his first experiment and refers in each case to the reduction of minium (Berthelot, op. cit., pp. 237, 245, 248). Only in one place (ibid., p. 238) does he refer to litharge, but this seems to refer back to an earlier experiment on the calcination of lead in which litharge was in fact produced, and not minium (ibid., pp. 236-237). 


\section{PHOSPHORUS AND MITOUARD}

With this apparatus Lavoisier repeated the experiment several times, using varying amounts of minium and charcoal before he hit upon the most effective proportions. Several bell jars were broken by the intense heat; and although he was unhappy at the small amounts of lead and charcoal he was obliged to use (because of the restricted focus of the burning glass), and at the necessity of using bell jars of large diameter (because of the intense heat in the neighborhood of the focus), he nevertheless found his result sufficiently decisive. The significance of this experiment was now far greater than when he had conceived it the previous summer; in the meantime, as we know, he had discovered that burning phosphorus and sulphur absorb large quantities of air, and he was now convinced that the addition of air accounted for the increase in weight of all substances that are burned or calcined.

\section{The Combustion of Phosphorus and Sulphur}

What then brought Lavoisier, during the period between August and late October, 1772, when he was obliged to postpone his experiment on the reduction of the calx of lead, to investigate the behavior of burning phosphorus and sulphur? There is no evidence, as we have seen, that either of these substances had interested him at any time before the autumn of 1772; he had never experimented with them, although the properties of phosphorus, in particular, had aroused the curiosity of a number of chemists.

This remarkable waxlike substance of extraordinary inflammability, with its striking property of shining in the dark, was still something of a novelty, though it had been 
known for more than a century. It was first discovered about 1668-1669 by an otherwise unknown Hamburg physician and chemist named Hennig Brand. ${ }^{6}$ Brand's secret was earnestly sought by the more reputable chemist, Johann Kunckel, who journeyed to Hamburg only to find that a Dresden friend, a certain Johann Daniel Krafft (or Kraft), had forestalled him and purchased the secret for 200 thalers. Krafft made a good thing out of demonstrating the new substance, traveling to England, where he displayed it at the Court of Charles II and to gatherings of curious scientists. It was thus that Robert Boyle, in September, 1677, first learned of it. Like Kunckel, Boyle was fascinated, but he could extract from Krafft only the information that the new substance was prepared in some way from animal or human material. Both Kunckel and Boyle, independently and by their own exertions, discovered that phosphorus could be made by distilling evaporated urine. Kunckel disclosed his method to a number of persons; but in a work published in 1678, devoted to describing phosphorus and its properties, he neglected to tell precisely how he made it. Boyle in 1680-1682 was the first to publish a general method of preparing phosphorus and the first to give a really scientific account of some of its chemical and physical characteristics. ${ }^{7}$

${ }^{6}$ A good summary of the discovery and early history of phosphorus is given in Mary Elvira Weeks, Discovery of the Elements (6th ed.; Easton, Pa., 1956), pp. 122-139, with a valuable bibliography. But Kopp (op. cit., III, 327-334) and Hoefer (op. cit., II, 174-175 and 191-198) are still worth consulting.

${ }^{7}$ Works of the Honourable Robert Boyle, IV, 379-404 and 469-495. Boyle's chief assistant in this work, Ambrose Godfrey Hanckwitz (1660-1741), became Europe's chief supplier of phosphorus. See Hellot in Mém. Acad. roy. sci. for 1737 (1740), pp. 


\section{PHOSPHORUS AND MITOUARD}

Boyle discovered that when phosphorus is ignited the product rapidly takes up moisture from the air to produce "a liquor almost as strong as spirit of salt," i.e., phosphoric acid. The acid was first carefully studied by the great German chemist, A. S. Marggraf (1709-1782), who prepared it from microcosmic salt, by burning phosphorus, and by treating phosphorus with nitric acid. ${ }^{8} \mathrm{He}$ carefully described the flocculent combustion product $\left(\mathrm{P}_{4} \mathrm{O}_{10}\right)$ and called it flowers of phosphorus, because of its physical resemblance to flowers of zinc and similar substances. $\mathrm{He}$ made the important observation that this strongly hygroscopic material, if weighed while still warm (i.e., before it could take up water from the air) proved to be markedly heavier than the phosphorus from which it was made. But Marggraf made no attempt to explain this interesting phenomenon, and his observation did not attract wide notice. ${ }^{9}$

During the eighteenth century phosphorus-which the French chemists usually called Kunckel's phosphorus or English phosphorus to distinguish it from other phosphorescent substances-was prepared by the laborious and unpleasant method of Kunckel and Boyle, as improved by Hellot and later by Marggraf. In 1771 Scheele described a better method, evidently discovered accidentally by his colleague Gahn. This new process, in which phosphorus was prepared from bones, soon replaced the

342-378; and R. E. W. Maddison in Notes and Records of the Royal Society of London, 2 (1954-1955), 168-173.

${ }^{8}$ See Hoefer, op. cit., II, 412, and Max Speter's article “Marggraf" in Bugge, Das Buch der grossen Chemiker, I, 228-239.

${ }^{9}$ This discovery was actually reported earlier by Godfrey Hanckwitz in Philosophical Transactions, 38 (1733-1734 [1735]), 58. 


\section{LAVOISIER-THE CRUCIAL YEAR}

more repulsive older one. It is possible, but not likely, that the "beau phosphore venant d'Allemagne," which Lavoisier obtained for his use in September, 1772, was made according to Scheele's method. At this time Marggraf's procedure was the one commonly used.

Among Lavoisier's contemporaries there was much curiosity about phosphorus and its properties. Even the general public could learn something about this astonishing substance, for the conjuror Comus-a man of some scientific pretensions and immense popularity-used it with spectacular success in his mystifications. ${ }^{10}$ Macquer included an exceedingly long article on phosphorus in his Dictionnaire de chymie of 1766 , with a history of the substance and a full account of Marggraf's experiments. From him we learn that his disciple, Baumé the apothecary, was skilled in preparing phosphorus by an improved version of Marggraf's process. ${ }^{11}$

One French chemist we know to have been working with phosphorus is especially deserving of mention, since Meldrum has suggested his possible influence on Lavoisier, a conjecture that has often been repeated. This was B. G. Sage, a chemist and mineralogist already mentioned for his proposed experiment on the reduction of lead exide. In 1769, in his Examen chymique de différentes substances minérales, Sage reported that such concretions as the famous bezoar stone and other sorts of calculi contained salts of phosphoric acid. ${ }^{12}$ Later he devoted

${ }^{10}$ For this man, whose real name was Nicolas Philippe Ledru, see Jean Torlais, "Un prestidigitateur célèbre," Histoire de la médecine, 5 (1955), 13-25.

${ }^{11}$ Dictionnaire de chymie (ed. 1766), II, 222-237.

12 Examen chymique de différentes substances minerales; essais sur le vin, les pierres, les bézoards, \& d'autres parties d'histoire, 164 


\section{PHOSPHORUS AND MITOUARD}

much space to discussing phosphorus and its acid in his Elémens de minéralogie docimastique, published early in 1772 , but much of what he said in this book was highly fanciful and unsupported by a single experiment. He described phosphoric acid as "l'acide marin altéré par la circulation dans les corps des animaux carnivores" and therefore classed it with the mineral acids. ${ }^{13}$ Sage accordingly tried to demonstrate the wide occurrence of phosphoric acid in the mineral kingdom, but rather unconvincingly, since he did not detect it in those minerals where it does in fact occur but believed that such diverse substances as borax, chalk, basalt, and the diamond were compounds of phosphoric acid. ${ }^{14}$

Meldrum, as we have seen, laid stress on the paper of Cigna that appeared in the May issue of Rozier's journal, which he thought could have influenced Lavoisier, since it "brought together numerous observations on the absorption of air" by burning phosphorus. This might be true, were it not for three things: (1) that Cigna in fact adds little to the observations of Stephen Hales, by whom he was strongly influenced and whom he frequently quotes; (2) that neither Hales nor Cigna clearly understood that air is chemically absorbed when phosphorus burns; and finally (3) that Lavoisier probably did not know the contents of Cigna's paper until many months later.

To take up the last objection first, there is persuasive evidence, which Meldrum overlooked, to show that La-

naturelle \& de chymie; traduction d'une lettre de Monsieur Lehmann, sur la mine de plomb rouge (Paris, 1769), pp. 85-103.

${ }^{13}$ Elémens de minéralogie docimastique (ed. 1772), pp. 4-5. 14 Ibid., pp. 22, 38, 111, 132-133. 
voisier had not read Cigna's memoir; or that, if he had, it made little or no impression upon him. For example, Lavoisier did not mention Cigna's work in the historical portion of the Opuscules, where he was at pains to bestow credit and to summarize all the important early work on "fixed air" and gases from Hales to Priestley, even including a short account of the work of Cigna's colleague, the Comte de Saluces, on the air released by the explosion of gunpowder. By the same token, Lavoisier did not send Cigna a complimentary copy of his book as he did, early in 1774, to Black, Priestley, De Smeth, Jacquin, and other pioneer pneumatic chemists. Nevertheless, he dispatched a copy, without specifying the recipient, to the Sociéte Royale de Turin. The gift was acknowledged by a letter from the Comte de Saluces, who noted the omission of all reference to his colleague and urged Lavoisier to look up Cigna's paper in the second of the three volumes of the Turin Mélanges he was sending Lavoisier in return. Later that year Lavoisier received a letter from another Italian scientist, Father Beccaria, in which the latter spoke of experiments of his own and pointed out that they were briefly mentioned in the paper Cigna had published in the Mélanges of the Turin scientific society. The passage to which Beccaria referred had indeed appeared in Rozier's French version of the Cigna paper; but Lavoisier was evidently unaware of it, for he wrote to Rozier in haste, on December 12, 1774, asking if there was still time to add an explanatory note to the paper he had submitted "Sur la calcination des métaux dans les vaisseaux fermés." And he added:

Il m'importe que le Public soit convaincu, le plutôt possible, que je n'ai point l'intention de m'approprier le travail d'autrui; 


\section{PHOSPHORUS AND MITOUARD}

\& je suis convaincu que la delicatesse en Litterature \& en Physique n'est pas moins essentielle qu'en Morale. Quoique l'experience du Pere Beccaria diminue de quelque chose la nouveauté de mes expériences, je vous avouerai cependant que sa Lettre m'a fait un tres-grand plaisir. ${ }^{15}$

Rozier had no difficulty in including Lavoisier's note (and indeed Lavoisier's letter to him) in the December, 1774, number of his journal. Lavoisier's note is followed by the passages from Beccaria's letter and the sentences in which Cigna summed up Beccaria's experiments. These last were evidently translated from the Latin of the Mélanges, as Lavoisier indicates, for the wording differs slightly from the French version in Rozier's journal.

This episode, together with Lavoisier's failure to mention Cigna in the Opuscules, makes it seem very likely that Lavoisier had not read Cigna's mainly physiological paper; he seems to have had his attention drawn to it more than two years after it had appeared in Rozier's journal. Yet I believe that even if he had read it, the paper would not have had the effect on him that Meldrum imagined, for neither Hales nor Cigna-and this is especially true of Cigna-really understood that air combined with burning phosphorus or sulphur!

To be sure, Hales had quite clearly stated in the Vegetable Staticks that two grains of phosphorus when burned "absorbed" on one occasion three cubic inches of air and at another time twenty-eight cubic inches; and he recorded

15 Observations sur la physique, 4 (1774), 452. The letters of Beccaria and Lavoisier and the passage from Cigna are reproduced in Oeuvres de Lavoisier-Correspondance, II, 461-462 and 465467. The letter of the Comte de Saluces was published for the first time by M. Fric (ibid., pp. 431-433). 


\section{LAVOISIER-THE CRUCIAL YEAR}

that when he ignited a large match made of linen rags dipped in melted sulphur, the burning match absorbed "198 cubick inches, equal to $1 / 10$ part of the whole air in the vessel." 16 Yet Hales, as Lavoisier was later to point out, ${ }^{17}$ leaves the reader somewhat confused as to what actually takes place. There are passages, like those just quoted, where he seems to suggest that the burning solid or its vapor really absorbs and fixes air during combustion, thus decreasing the volume of air in the vessel. Elsewhere, however, he clearly states his opinion that the shrinkage in volume is due to a weakening of the elasticity of air. This elasticity, he writes, appealing to the authority of Isaac Newton, "is supposed to consist in the active aerial particles repelling each other with a force which is reciprocally proportional to their distances." 18 Air charged and clogged with vapors loses this elasticity and so shrinks in volume. The vapor of such burning substances as sulphur powerfully attracts the elastic particles of air:

And therefore the Candle and Matches ceasing to burn, soon after they are confined in a small quantity of air, seems not to be owing to their having rendred that air effete, by having consumed its vivifying spirit; but should rather be owing to

${ }^{16}$ Exper. CIII, pp. 226-227. Cf. ibid., Exper. LIV, p. 169, and Exper. LXXVI, pp. 182-183.

17 "M. Hales a encore remarqué que le phosphore ou plûtôt le pyrophore de M. Homberg diminuait le volume de l'air dans lequel on le brûlait. ... Quant à la diminution du volume de l'air qui s'opère pendant la combustion de quelques corps, tantôt il l'attribue à la perte de son élasticité, tantôt il semble croire que cet air est réellement fixé et absorbé pendant la combustion, et son ouvrage semble laisser quelque incertitude à cet égard" (Oeuvres de Lavoisier, I, 459).

18 Vegetable Staticks, Exper. LXXXIX, p. 207. 


\section{PHOSPHORUS AND MITOUARD}

the great quantity of acid fuliginous vapours, with which that air is charged, which destroy a good deal of its elasticity, and very much clog and retard the elastick motion of the remainder. ${ }^{19}$

It is probable, then, that when Hales referred to the shrinkage of air volume in these experiments as an absorption of the air, he was using a mere shorthand expression to describe the appearances. This is certainly true of Cigna, who relies heavily on Hales but is somewhat more explicit in interpreting the chemical events. ${ }^{20}$ In the passage which so impressed Meldrum, Cigna writes that two grains of phosphorus, lighted and enclosed in a container, absorb twenty-three inches of air. But this is evidently only a manner of speaking, for he explains immediately afterwards: "Les flammes diminuent le ressort de l'air, non en l'absorbant, mais en exhalant des vapeurs qui diminuent la force répulsive des parties de ce fluide avec lesquelles elles se mêlent." ${ }^{21}$

Though Hales (and Cigna after him) had clearly shown that the volume of air in which phosphorus or sulphur are burned diminishes as a result of the combustion, their explanations may well have seemed confusing to others besides Lavoisier. There was, however, one fact which, if it had been known and considered in the light of this phenomenon, could not but have set investigators

${ }^{19} \mathrm{Ibid}$., Exper. CXVII, p. 273. It should be pointed out that Hales had found a decrease in weight of burnt phosphorus before it had run per deliquium. See below, note 22.

20 "Dissertation de M. Cigna, sur les causes de l'extinction de la lumière d'une Bougie, \& de la mort des Animaux renfermés dans un espace plein d'air," Introduction aux observations, II, 84-105.

${ }^{21}$ Ibid., p. 97. The italics are mine. 


\section{LAVOISIER-THE CRUCIAL YEAR}

on the right track. This was the observation that both sulphur and phosphorus increase markedly in weight when they are burned. Marggraf, who, as we have seen, first described phosphoric acid and the production of flowers of phosphorus, had noted, but not successfully explained or adequately emphasized, that when this substance is produced by burning phosphorus freely in air it is markedly heavier than the starting material. Rather surprisingly, this observation was not mentioned by Macquer in the article on phosphorus in his Dictionnaire, though he treated Marggraf's work at great length.

Sage, in his Elémens de minéralogie docimastique, made a similar but less precise observation. He mentioned the production of phosphorus by reduction of the acid and the reverse reaction by which phosphorus left exposed to the air is converted into a colorless, transparent acid weighing three times as much as the phosphorus. He noted the familiar deliquescent property of the acid and remarked that it weighed considerably more than the starting material. Attributing all or most of this increase in weight to the addition of water from the air, he estimated that one part of acid combines with at least two parts of water. ${ }^{22}$ Meldrum suggested that this passage in the often speculative book of Sage may have influenced Lavoisier, perhaps first arousing his interest in phosphorus or calling

${ }^{22}$ Elémens de minéralogie docimastique (ed. 1772), p 5. Cf. Hales: "When 3 grains of Phosphorus were weighed, soon after it was burnt, it had lost half a grain of its weight; when two grains of Phosphorus was weighed, some hours after it was burnt, having run more per deliquium by absorbing the moisture of the Air, it had increased a grain in weight" (Vegetable Staticks, Exper. LIV, p. 169). 


\section{PHOSPHORUS AND MITOUARD}

his attention to the greater weight of the phosphoric acid. ${ }^{23}$ Lavoisier certainly knew the book, ${ }^{24}$ for his name was mentioned by its reviewer, probably Rozier himself, in the April issue of the Observations sur la physique; ${ }^{25}$ and in a later paper on the analysis of mineral waters Lavoisier seems to be referring to Sage when he expresses doubt that "a modern author" is correct in asserting that phosphoric acid belongs to the mineral realm and therefore that its salts are to be found in mineral waters. ${ }^{26}$ But there is no reference to the production of phosphoric acid or to the increase in weight. I doubt whether Sage's rather confused observation, in which the hygroscopic properties of the acid obscured the more significant weight change when the phosphorus turns into acid, had any influence on Lavoisier, as most authors, following Meldrum, have claimed.

${ }^{23}$ Meldrum, loc. cit., pp. 15-16.

24 There is no record that Lavoisier owned a copy of this book, though he possessed the two-volume second edition of 1777, for it is recorded in the inventory of 1793 (Biblio. de l'Arsenal, 6496) and in the "Bibliothèque de Madame la Comtesse de Rumford," Tome I, Catalogue, p. 70. That Lavoisier owned the second but not the first edition of Sage's work suggests that it was the appearance of the expanded edition of 1777 that led Lavoisier to refute Sage's views concerning phosphorus in a paper he read in that year to the Academy (Oeuvres de Lavoisier, II, 139-152). If this is true, the value of Lavoisier's paper as evidence for Sage's presumed influence in 1772 is diminished to the vanishing point.

${ }^{25}$ The reviewer wrote: "Il semble que l'Auteur auroit dû citer le travail de M. Lavoisier sur le gypse, aussi instructif pour le fond, que satisfaisant pour ses résultats" (Introduction aux observations, II, 53).

26 "Mémoire sur l'usage de l'esprit-de-vin dans l'analyse des eaux minérales," Oeuvres de Lavoisier, II, 29-37. 
At least as likely a source for this significant piece of information is a brief reference in a book Lavoisier knew well: Guyton de Morveau's Digressions académiques. Here, in the same essay in which he announced the general fact of the increase in weight of calcined metals, Guyton recorded that when he ignited twenty-two grains of phosphorus by gentle heating in a retort he found the resulting product to be fifteen grains heavier. ${ }^{27}$ Guyton worked with phosphorus as Lavoisier was later to do: that is, he prepared the "flowers of phosphorus" by burning, rather than by the slow, spontaneous combustion of phosphorus in air, the method that Sage employed; and he therefore realized that the absorption of water could not be mainly responsible for the gain in weight. Evidently unaware of Marggraf's observation, Guyton was later to claim credit for this discovery, though at the time its significance escaped him, as well it might in view of his theories about calcination. ${ }^{28}$

Be that as it may, there is no real evidence that any of this work-the paper of Cigna, the book of Sage, or the observation of Guyton de Morveau-drew Lavoisier's attention to the study of phosphorus or to the problem of combustion. We have seen that he came to study combustion by another route, through his interest in the cal-

${ }^{27}$ Digressions académiques, p. 252 , note 1 . This passage was first noted by Max Speter. See Chemisch Weekblad, 28 (1931), 80-81; also Chemiker-Zeitung, 55 (1931), 994. Speter even claimed that by having the memoir of October 20,1772 , initialed Lavoisier was seeking to assure himself priority over Guyton, as well as over Priestley and Mitouard. This is doubtful.

${ }^{28}$ Guyton wrote: “J'avois observé en 1772, que le phosphore acquérait une augmentation de poids sensible en passant à l'état d'acide" (Encyclopédie méthodique-Chimie, I (1786), 629. 
cination and reduction of metals. In all likelihood he was impelled to study phosphorus, not by anything he encountered in his reading, but by a purely routine episode of academic business; or so at least the evidence would suggest.

\section{Lavoisier and Mitouard}

It will be recalled that our earliest trace of Lavoisier's interest in combustion and the first reference to his experiments on phosphorus are supplied by the note of September 10, 1772, discovered and printed by Meldrum in 1932. ${ }^{29}$ This recorded the purchase of a sample of German phosphorus from the Parisian pharmacist, PierreFrançois Mitouard or Mitouart, whose name has appeared several times in this narrative. I believe, though what I shall have to say is necessarily conjectural, that it was a memoir of Mitouard on phosphorus, which Lavoisier agreed to referee for the Academy of Sciences, that drew his attention to this substance and led to his now-classic experiments of the autumn of 1772 .

That Mitouard's work on phosphorus was the starting point of Lavoisier's classic investigations was first strongly urged by Max Speter in a suggestive, but ill-fated and somewhat ill-considered, article published in $1926 .{ }^{30}$ Speter was the first to point out that Mitouard read to the Academy in the fall of 1772 a paper that dealt with the products obtained by distilling phosphorus; at the same time he

${ }^{29}$ See above, pp. 6-8.

${ }^{30}$ Speter, "Kritisches über die Entstehung von Lavoisiers System," loc. cit., pp. 578-582. Three years later Speter presented this theory unchanged and at length in Das Buch der grossen Chemiker, I, 313-316. 


\section{LAVOISIER-THE CRUCIAL YEAR}

called attention to the report on this memoir submitted by Lavoisier and Macquer under the date of December 16, $1772 .^{31}$ Speter emphasized that in the document Lavoisier had singled out as "très-remarquable" Mitouard's passing observation that the weight of the phosphoric acid produced was greater than that of the "poudre phosphorique" from which it was prepared, and that he had called special attention to Mitouard's suggestion that this phenomenon was due either to the humidity of the air or to the air itself. Speter was further impressed by the striking resemblance, the frappante Ahnlichkeit, of this passage to the first sentence of Lavoisier's sealed note of November 1 (in which Lavoisier attributed the increase in weight of sulphur and phosphorus to the "prodigious quantity of air" that is fixed during combustion).

Speter knew-from a reference made by Berthelotthat Lavoisier had begun his work on phosphorus on September 10; but he did not know, though the fact would have interested him extremely, that Lavoisier purchased his first sample of phosphorus from this same

${ }^{31}$ First published in Rozier's journal in 1774 under the title: "Rapport fait à l'Académie des Sciences par MM. Macquer \& Lavoisier, d'un Mémoire de M. Mitouard, dans lequel il s'est proposé d'examiner différentes substances qui se trouvent dans les vaisseaux où l'on distille le phosphore par le procédé de M. Margraff [sic], \& que l'on a coutume de rejetter, quoiqu'il fût encore possible d'en tirer parti" (Observations sur la physique, 3 [1774], 421-423). It was reprinted with minor changes, an abbreviated title, and the addition of a first paragraph restating part of the longer title, in Oeuvres de Lavoisier, IV, 141-143. This new paragraph makes it clear that Lavoisier was the author of the report, for it begins: "L’Académie nous a chargés, M. Macquer et moi, de lui rendre compte, etc." 
Mitouard, for on this point Berthelot was silent. Speter was not troubled by the circumstance that the report of Lavoisier and Macquer was dated as late as December 16; in spite of this fact, he was convinced that Lavoisier had seen Mitouard's memoir before October 20, perhaps as early as September; and he argued that the memoir of October 20-which at this time he knew only by hearsay - had been paraphé by Fouchy to ensure Lavoisier priority with respect to Mitouard's suggestion. In a later paper (1931) ${ }^{32}$ Speter felt impelled to modify his view after learning from Paul Dorveaux, of the Academy of Sciences in Paris, that Mitouard's memoir had not been submitted officially until December 12,1772 , the very day the memoir was read to the Academy. ${ }^{33}$ In consequence, Speter altered his hypothesis to suggest that Lavoisier and Macquer had prior knowledge of the contents of Mitou-

32 Speter, "Lavoisierana," loc. cit., p. 994, note 17. In a paper published the following year, in which he printed for the first time (anticipating Meldrum by several months) Lavoisier's outline memoir of October 20, Speter is less explicit in his claims for Mitouard. Here he writes: "Warum und wem gegenüber diese Prioritätssicherungen Lavoisiers? Er selbst gab in seinem, vermutlich 1792 verfassten, nach seinem Tode von seiner Witwe veröffentlichten historischen Rückblick auf seine epochalen Arbeiten über Metallverkalkung an, dass er sich gegenüber den englischen Gelehrten (Priestleyl) das Eigentum an seiner Entdeckung sichern wollte. Verschiedene Indizien wiesen widerum auf eine Art Themenbesitzergreifung gegenüber dem Pariser Apotheker-Chemiker Mitouart und dem Dijoner Advokaten-Chemiker Guyton de Morveau hin." He makes no comparison between the content of Mitouard's paper and Lavoisier's memoir ("Die entdeckte Lavoisier-'Note' vom 20. Oktober 1772," loc. cit., p. 107).

33 Paul Dorveaux, "Quelques mots de plus sur Mitoüart," Revue dhistoire de la pharmacie, 19 (1931), 245-260. 
ard's memoir, else it would be hard to understand how they could have rendered their report in the brief space of four days after Mitouard presented it.

In 1932 A. N. Meldrum-who seems to have seen only Speter's paper of 1926-strongly attacked the idea that Mitouard could have influenced Lavoisier. This he did chiefly on the ground that, by assuming the memoir to have been "held back for months whilst Lavoisier made illicit use of it," Speter was reflecting in a manner that was "wanton and deplorable" on the Academy of Sciences, its Secretary, and on Lavoisier himself. Nor was Meldrum ready to believe that Mitouard-a man he described as of no real eminence, not mentioned by Poggendorff or Kopp, and whose work consisted of mere "idle speculation"-could have been the source of Lavoisier's inspiration. Any similarity between Lavoisier's November note and Mitouard's speculations could, he contended, just as well prove that Lavoisier had influenced Mitouard as show the reverse. Meldrum's most telling argument was that Mitouard did not read his memoir to the Academy until December 12 (a fact Speter did not know in 1926); and this, Meldrum insisted, must have been soon after he completed his experiments, for Mitouard "had ready access to the Académie," and on two occasions the previous spring had presented to the Academy the results of experiments carried out only a few days-on one occasion only two days-earlier. ${ }^{34}$

Meldrum's arguments seem to have struck most scholars 34 "Lavoisier's Three Notes on Combustion," loc. cit., pp. 24-27. Meldrum also remarked that Mitouard, in contrast to Lavoisier, "worked with a derivative of phosphorus." This is not quite accurate; there is no evidence that Meldrum had read Mitouard's memoir; he probably judged it from Lavoisier's summary. 
as conclusive; Speter's theory has been totally neglected by the more recent students of Lavoisier's work, perhaps because of Meldrum's attack, perhaps from a reluctance of French and English historians of chemistry to read the German literature. Nobody until now has seen fit to mention, let alone re-examine, the theory of the possible influence of Mitouard on Lavoisier. Yet with Speter's conjecture consigned to oblivion, we are left with the unexplained coincidence of Lavoisier's purchase of the phosphorus sample from Mitouard in September and his authorship of a report on Mitouard's phosphorus experiments on December 16, events which neatly bracket the period of Lavoisier's own classic experiments on the same substance.

Although I certainly do not accept Speter's theory, even as he eventually modified it, and cannot believe that Lavoisier had the note of October 20 initialed in order to ensure himself of priority with Mitouard specially in mind, the impression is unavoidable that there is some connection between Mitouard's rather crude investigations and the brilliant discoveries of Lavoisier. The sticking point is, of course, the late date at which Mitouard presented his results to the Academy. Although we can no longer believe, as Speter for a time did, that the Academy delayed for several months before reporting on a memoir that had been officially submitted to it, is it not possible that Lavoisier and Macquer knew of the contents of the memoir and perhaps had it in their possession as early as late August or the beginning of September? There are reasons to think that this may have been the case. Meldrum was not struck, as Speter was, by the significant fact that the Lavoisier-Macquer report was dated only four days 
after Mitouard had submitted his memoir to the Academy; yet this seems a surprisingly short time for these conscientious scientists to have reviewed it with care. Nor did Meldrum note (as Speter had done in his paper of 1931) that Lavoisier and Macquer, on the same day that they reported on the phosphorus paper, submitted reports on two other memoirs of Mitouard, memoirs which had been read to the Academy the previous spring and which had apparently suffered just the sort of delay Meldrum felt was intolerable to imagine. All this is suggestive, but hardly persuasive.

More convincing, I believe, are certain important similarities that can be observed between the language of Lavoisier's "memoir-torso" of October 20 and that of Mitouard's paper. These are more striking than the resemblances Speter thought he discerned between Lavoisier's note of November 1 and the Lavoisier-Macquer report on Mitouard's memoir. Neither Speter nor Meldrum seems to have looked at Mitouard's unpublished paper, though it could readily have been consulted in the archives of the Academy of Sciences. Such a comparison is quite revealing.

Though not a major contribution to science, Mitouard's investigation is a respectable piece of work that does not deserve Meldrum's harsh condemnation ${ }^{35}$ Mitouard's purpose was not to theorize about the production of phosphoric acid but to investigate the by-products left behind when phosphorus was prepared by what he described as

35 "Examen de plusieurs substances qui se trouvent dans les vaisseaux ou l'on distille le phosphore que l'on rejette comme inutile quoiqu'il soit possible d'en tirer un bon parti. Par M. Mitoüard." This manuscript, thirteen pages in length, in Mitouard's own hand, is preserved in the archives of the Academy of Sciences. 


\section{PHOSPHORUS AND MITOUARD}

Marggraf's laborious and costly method. He had observed that when the crude phosphorus prepared from urine was purified by distillation, in the final step of this process, there was a marked loss of material. Some of the missing phosphorus he felt might be recovered from the reddishbrown scales that adhered to the neck of the distillation flask or from the reddish powdery mass that collected in the bottom of the receiver. The scales, we can now see, were chiefly composed of the red allotropic form of phosphorus, which Mitouard seems to have been the first to describe; and the powdery material was probably impure phosphorus pentoxide mixed with some of the red phosphorus. The latter he was able to separate, at least partially, as insoluble reddish particles by washing the flocculent powder with distilled water. To his own satisfaction Mitouard showed that both forms of this reddish material consisted of relatively pure phosphorus altered in some mysterious way. When he heated samples of this red phosphorus, they burned brightly and produced the familiar white sublimate which was rapidly converted into an acid liquor.

In his "memoir-torso" of October 20, Lavoisier describes the same substances, and in words that closely resemble Mitouard's. The red phosphorus, which appeared to Mitouard as "écailles d'un brun rougeatre" or as "cette poudre jaune orangée" is described by Lavoisier as having a "couleur jaune rouille de fer." It consists, said Mitouard, of "un phosphore avec le moins de principe inflammable possible," words which Lavoisier appears to echo when he writes that it is phosphorus "qui a perdu une partie de son principe inflammable." Of the acid liquor into which the white vapors are transformed, Mitouard wrote: "Cet 
acide est dans son genre ce qu'est l'acide sulphureux volatile à l'acide vitriolique pur." On evaporating it, "on la concentre au point de luy donner la consistence d'une gelée." Lavoisier, who worked more carefully and astutely, starting from his sample of pure phosphorus, set down a similar observation in his memoir. When he burned the phosphorus under a bell jar, he produced a white sublimate (the pentoxide), which he identified as phosphoric acid in an absolute degree of concentration, "tel à peu près que l'huile glaciale de vitriol."

The verbal parallels are too striking to be fortuitous. Even if two men might be led independently to describe similar appearances in similar terms, is it likely that they would interpret their observations in such identical fashion? Why should both men suggest that the red scales consisted of phosphorus that had lost some of its phlogiston? And if it is obvious why Mitouard could compare his concentrated phosphoric acid to oil of vitriol, it is less clear why Lavoisier should have applied this analogy to the solid pentoxide. Yet all this makes sense if Lavoisier was familiar with Mitouard's memoir before he set down his own findings late in October.

That this was the case is further suggested by a passage of the Lavoisier-Macquer report on Mitouard's memoirthe passage, indeed, which had so impressed Speter. Here Lavoisier wrote:

Ce qui nous paraît très-remarquable, c'est que, à quelque degré de concentration qu'on porte cet acide [Mitouard's liquid phosphoric acid], son poids est toujours supérieur à celui de la poudre phosphorique qu'on avait employée. M. Mitouard 180 
attribue ce phénomène à l'humidité de l'air ou à l'air lui-même contenu dans les vaisseaux où se fait la combustion. ${ }^{36}$

By the time he submitted his report (on December 16) Lavoisier had observed in the course of his own experiments the "phénomène singulier" that the concentrated acid (in his case, the pentoxide, not the liquid) was substantially heavier than the phosphorus that had produced it, even though a small quantity of the phosphorus had been converted into the inactive allotropic form. This increase in weight, he felt sure, must be due to the absorption of air. It is therefore surprising to find him referring on December 16 to this increase in weight as "trèsremarquable," as he does when describing Mitouard's work. Either he was deliberately concealing his recently acquired knowledge (in which case he would have been wiser, if scarcely more ingenuous, to pass this point over in silence, rather than single it out for comment) or he had actually written the report on Mitouard's experiments before the true explanation of this weight effect had been proved to his satisfaction by the end of October. In the light of all the evidence, I am inclined to accept the second explanation and to believe that Lavoisier must have had Mitouard's memoir in hand before October, and even that he knew of its contents or of the character of Mitouard's results before he purchased his now-famous sample of phosphorus in early September. I think also that he must have completed his written report before, rather than after, he had carried out his own more significant experiments. Later, when Mitouard formally submitted his mem${ }^{36}$ Oeuvres de Lavoisier, IV, 142. 
oir in December-or so I read the events-Lavoisier simply turned in, in his and Macquer's name, the unaltered report that he had written earlier, rather than rewrite it in the light of his newer information. This conjecture does something to explain, moreover, the curious speed with which the report was submitted.

One can only guess at what actually led up to these events, but I think it extremely likely, for reasons I shall try to make clear, that Lavoisier and Macquer were responsible for urging Mitouard to present his memoir to the Academy as soon as convenient after the Academy's autumn recess, which was regularly observed between early September and the rentrée publique of St. Martin's day, about the middle of November. They may have agreed in advance to referee the paper Mitouard was to present; and if so-since it was often the custom for the rapporteurs to repeat certain of the key experiments contained in a memoir submitted to the Academy for approval -it was perhaps for this purpose that Lavoisier, early in September, purchased the famous sample of German phosphorus from Mitouard. To give these conjectures any substance, we should have to show that Macquer and Lavoisier were in some manner closely associated with Mitouard, that they esteemed him as a chemist, and that there was some reason for encouraging him in this fashion. The little biographical information we possess about this obscure apothecary was assembled through the diligence of Paul Dorveaux, whose findings we may summarize here. ${ }^{37}$ Mitouard had been born in 1733 , in

${ }^{37}$ On Mitouard see P. Dorveaux, "Le cervelet de Voltaire et les Mitouart," Bulletin de la Société d'histoire de la pharmacie, no. 44 (November, 1924), pp. 409-421. I have not chosen to 


\section{PHOSPHORUS AND MITOUARD}

Beauchastel en Vivarais, the son of a salt-tax official (contrôleur au grenier à sel) of that town. After serving his apprenticeship as a pharmacist and passing the examination for the maitrise, he took the master's oath on September 2, 1761, and purchased an apothecary shop in the rue de Beaune, which soon became one of the best in the quarter. Here in his laboratory he began, in November, 1766 , a course of private chemical lectures, which he continued to give each winter for twenty years. He was obviously respected for his professional skill. The future aeronaut, Pilâtre de Rozier, was for a time his apprentice. And in 1777 Mitouard was chosen to be the pharmacist in attendance during the last illness of Voltaire, furnishing the medicines which had been prescribed for the expiring philosopher by the famous Dr. Tronchin. Mitouard embalmed the corpse, rather botching the job, as it turned out; and so he was able to take possession of Voltaire's brain, preserve it in alcohol, and display it in his shop for many years to the delight of curious visitors. In 1781 Mitouard was named demonstrator in chemistry at the newly founded Collège de pharmacie (where in fact he had lectured since its foundation in 1777) and taught there until his death at the age of 53 on September 11, 1786. He published almost nothing, which explains why Meldrum could not find him mentioned in the chief biographical and chemical reference works. But he was not, it turns out, as poor a chemist as Meldrum would have us believe. As Speter emphasized in a footnote to his paper of 1931,

follow Dorveaux in his rendering (Mitoüart or Mitouart) of this chemist's name but have retained the more common spelling used by Rozier, by Dumas in the Oeuvres de Lavoisier, and by Speter and Meldrum. 
Mitouard had been known to Macquer and Lavoisier for some time before September, 1772. Our forgotten pharmacist was one of those who, like Macquer and Lavoisier in August, 1771, had witnessed the destruction of the diamond by Darcet and Rouelle at the Jardin du Roi. ${ }^{38}$ In March, 1772, Mitouard made his first bid for recognition by the Academy of Sciences by appearing before it to present the prospectus of a work he proposed to prepare, for the Academy's series on the arts and crafts, on the "Art du peintre vernisseur et doreur."

At this time Mitouard was following closely the investigations on the diamond being carried out in the spring of that year; in fact he skillfully repeated and extended some of the work and offered to pay the cost of further largescale experiments, if Macquer and Lavoisier would perform them. It is particularly significant that he continued his association with these scientists during the summer of 1772. When the Academy formally gave permission for the use of their great burning glass, Mitouard was invited to take part in this project; ${ }^{39}$ and the record indicates that Mitouard did in fact play the role of observer, if not of very active participant, in the burning glass experiments; for on August 29 he brought the workers samples of safran de mars (iron sulphide) and of diaphoretic antimony to

38 See above, p. 82.

${ }^{39}$ Macquer (Introduction aux observations, II, 612-616) mentions only that he and Lavoisier had been invited by the Academy to join with Cadet and Brisson in these experiments. But Lavoisier tells us, in his manuscript account, that Cadet and Brisson "inviterent dans cette vue M. Macquer Lavoisier et Mitouard de Concourir a leur objet et ils convinrent entre eux de travailler de Concert a Ce grand ouvrage" (Lavoisier papers, dossier $72 \mathrm{~J}$, fol. 1 verso). 
be subjected to the heat of the Tschirnhausen lens. On October 7 Mitouard did even better and provided a ruby for the experiments. ${ }^{40}$

Mitouard's associates did not, quite evidently, share modern scholars' low opinion of his work, and they were right, at least as far as Mitouard's diamond experiments of the spring of 1772 are concerned. With Cadet-and using the same furnace and the same apparatus employed by the three principal collaborators-Mitouard attempted to distill diamonds, but without conclusive results. More successful were the experiments in which, following the earlier suggestion of Maillard, he sought to protect the diamond from the effects of heat by using various "intermediaries." These experiments were carried out in his own laboratory in the rue de Beaune in the presence of Macquer, Lavoisier, Cadet, and other members of the Academy. ${ }^{41}$

Taking three diamonds, he sealed one in an empty piece of clay pipestem, surrounded another by chalk in a second pipestem, and protected a third in the same manner with powdered charcoal. Each pipestem was then placed inside a nest of tightly closed crucibles. Forcing his furnace to a higher temperature than the others had used, Mitouard heated the diamonds strongly for three hours. At the end of the experiment the diamond in the empty pipestem and the one embedded in chalk were found to have lost their polish and the sharpness of their angles and had decreased in weight, whereas the diamond

40 Oeuvres de Lavoisier, III, 301 and 320. Speter describes Mitouard's role as that of "passiver Spender von Versuchsmaterial" in these experiments. See Das Buch der grossen Chemiker, I, 314. ${ }^{41}$ Introduction aux observations, II, 112-116. 
protected by charcoal remained totally unaffected. To exclude the possibility that the divergent results in the three cases might have been due to differences in the diamonds, he significantly varied the next experiment by interchanging the samples. The diamond that in the first experiment had been protected by charcoal was now surrounded with a powder of calcined hartshorn, the one he had embedded in chalk was placed in powdered charcoal, and the one that had been unprotected was put in powdered glass. As in the first experiment, only the diamond protected by charcoal emerged without alteration. From these results Mitouard concluded that although diamonds can be readily destroyed by strong heat if exposed to the air, when air is effectively excluded and when they are protected by substances like charcoal which contain much phlogiston, they can resist the heat of the furnace and indeed avoid any semblance of damage. Mitouard compared this behavior of the diamond with that of antimony and zinc, substances he knew to resist calcination if protected by powdered charcoal. There is no doubt that Mitouard strongly suspected that the destruction of the diamond was the result of a combustion.

Lavoisier and Macquer had nothing but praise for these experiments of Mitouard. Lavoisier gave a full and respectful account of them in his general summary of the work on the diamond. ${ }^{42}$ And in the first of their reports, made to the Academy on December 16, Lavoisier and Macquer spoke approvingly of Mitouard's diamond experiments of the previous spring. ${ }^{43}$ In their second report,

${ }^{42}$ Oeuvres de Lavoisier, II, 54-56.

${ }^{43}$ Dorveaux, "Quelques mots de plus sur Mitoüart," loc. cit., pp. 256-257. 


\section{PHOSPHORUS AND MITOUARD}

dealing with his memoir on phosphorus, they wrote as follows:

Ce mémoire de M. Mitouard nous a paru contenir des observations très-intéressantes, propres à répandre de nouvelles lumières sur la nature du phosphore et de son acide; il y donne d'ailleurs un moyen simple et peu dispendieux d'obtenir l'acide de phosphore en abondance, en le combinant à la base du nitre, et le procédé ne manquera pas de faciliter les recherches de ceux qui voudraient faire une étude particulière de la nature de cet acide. ${ }^{44}$

The rapporteurs recommended that all three of $\mathrm{Mi}$ touard's memoirs be printed in the Academy's Mémoires des savants étrangers. Such publication, it should be remembered, often preceded or accompanied the election of candidates to membership in the Academy. It is of some importance for our reconstruction of these obscure events to learn that this was supposed to be the case here.

Almost certainly with the encouragement of Macquer and Lavoisier, Mitouard was at this time an active candidate for membership in the Academy of Sciences and was relying on the active support of the academicians who appreciated his work. Precisely at this time a place of adjoint chimiste fell vacant, as a result of Lavoisier's promotion, on August 29, 1772, from the rank of adjoint to that of associé. Paul Dorveaux pointed out that Mitouard's was one of seven names put up at the election, scheduled for December 23, 1772, to find someone to fill Lavoisier's vacant chair. Mitouard, it should be remarked, was not successful; instead, his fellow apothecary, Antoine Baumé,

${ }^{44}$ Oeuvres de Lavoisier, IV, 143. 
for whom there was especially strong support, was chosen, with the young chemist Bucquet next in line. ${ }^{45}$ Nor did Mitouard even have the consolation of seeing his memoirs published, as Lavoisier and Macquer had urged, in the Savants étrangers. But this is beside the point. What emerges is that Mitouard's appearance before the Academy on December 12 to read his memoir on phosphorus was clearly intended to further his candidacy, for this was to be voted on eleven days later. The strange procedure by which Lavoisier and Macquer reported so soon after December 12, not only on Mitouard's phosphorus memoir, but also on his earlier diamond papers, is at once easier to understand and clearly marks these men as at least to some extent supporters of Mitouard's cause.

To sum the matter up, I think it probable-though perhaps beyond the reach of solid proof-that after his promotion in August, 1772, Lavoisier encouraged Mitouard, with whom he had collaborated and whose work he esteemed, to take the necessary steps to convince the Academy of his worth. Mitouard would then have described to Lavoisier his work on phosphorus or even put the memoir, or a draft of it, in his friend's hands, so that

45 Dorveaux quotes the Procès-verbaux as follows: "L'Académie ayant procédé, suivant la forme ordinaire, à l'élection de deux sujets pour remplir la place d'adjoint chymiste vacante par la promotion de M. Lavoisier, la Classe a proposé Mrs. Demachy, Baumé, Mitoüart, Le Veillard, Bucquet, Delisle et Laborie, entre lesquels les premières voix ont été pour $\mathbf{M}$. Baumé et les secondes pour $\mathbf{M}$. Bucquet." See his "Quelques mots de plus sur Mitoüart," loc. cit., p. 257. The Macquer correspondence reveals that the Duc d'Ayen, though not yet an honoraire of the Academy, sought to round up support in favor of Baumé's election. But Macquer was doubtless already inclined to favor his old associate. See Macquer correspondence, Bib. nat. MS Fr. 12305, I, nos. 31-34. 
he could study it, repeat certain of the experiments, and have a report in readiness. Thus, even though Mitouard could not present the memoir much before the electionfor the Academy would be closed during the annual autumn recess-the customary formalities could be quickly satisfied soon after the reconvening of the Academy in mid-November. As far as I can see, this reconstruction has at least the merit of accounting for most of the mysteries and peculiarities of the Mitouard episode.

Speter argued that Mitouard's casual suggestion that the addition of air might explain the greater weight of phosphoric acid led Lavoisier to embark for the first time on the study of combustion. My own interpretation is somewhat different. I think it may have been by some such train of events as I have proposed that Lavoisier was brought to investigate phosphorus. Perhaps, too, Mitouard's casual aside led him to explore the role of air in the combustion of this substance. But, as I have tried to show in this study, Lavoisier already had more than a faint suspicion, when he embarked on the phosphorus experiments, that the chemical participation of air could explain the analogous phenomenon of the gain in weight of calcined metals and the effervescences observed when they are reduced. He had already leaped the important and difficult mental hurdle-a hurdle raised and sustained by the widespread prejudice that air could not be a chemically significant substance-and he was probably chafing to get his hands on the Tschirnhausen lens to test his conjecture in the case of minium. The accident of having to evaluate Mitouard's work on phosphorus, perhaps stimulated by Mitouard's remark about the possible role of air, gave Lavoisier the unexpected opportunity as well as the 
incentive to explore an interesting possibility: namely, that what he believed to take place in the calcination and reduction of metals might also be true, as Mitouard seemed to think possible, in the case of burning phosphorus, a substance, incidentally, that could be readily studied without the use of the burning glass.

The course of events would then have been different from that which Lavoisier seems to describe in the sealed note of November 1 and this, I am persuaded, was the case. At the very beginning of these experiments on phosphorus, as the note of September 10 makes clear, Lavoisier set out to discover whether phosphorus absorbed air when it burned. As even Meldrum remarks: "It is noteworthy that he aimed, not at making a discovery, but at the verification of what had been reported." ${ }^{46}$

Whether Lavoisier saw Mitouard's memoir before September or whether he merely learned of Mitouard's speculations from casual conversation, it is likely that Lavoisier seized upon the suggestion that air might combine with burning phosphorus. We have seen that this passing suggestion made a deep impression on him. But this clue could only have fanned into flame a spark already aglow in Lavoisier's active mind. As I have tried to show, it was not Mitouard's memoir, still less the references by Sage, Cigna, or Guyton de Morveau to the odd behavior of phosphorus, nor even the experiments on the diamond, which first set him on the path to his great experiments on combustion. By his own testimony Lavoisier was led in the first instance to speculate about the nature of chemical

46 "Lavoisier's Three Notes on Combustion," loc. cit., p. 19. Meldrum, of course, had in mind the passages in the writings of Cigna and Sage. 


\section{PHOSPHORUS AND MITOUARD}

effervescence, especially those effervescences observed when metallic calxes are reduced; but it was the remarkable experiments of Guyton de Morveau on the calcination of metals and Hales's theory of fixable air, now more significant in the light of the rumors that were beginning to circulate about new British discoveries of the same sort, that came together in his mind to suggest the hypothesis he proposed to test with the burning glass. It seems, therefore, to have been a mere accident that this hypothesis was first confirmed with phosphorus and then with sulphur, rather than by the experiment on the reduction of metallic calxes which he had envisaged as early as August 8, 1772. 